\section{Unesco and Termite Research}

Problems of termite research were discussed at Unesco House in Paris during June 12-15 by a subcommitteo rocently set up on the recommendation of the International Advisory Committee for Humid Tropics Research. Members of the sub-committeo attending were Dr. R. L. Araujo (Sao Paulo), Prof. K. Gösswald (Würzburg), Prof. P. P. Grassé (Paris), Mr. W. V. Harris (London) and Dr. M. L. Roonwal (Calcutta). Also present as observers wero Dr. E. Ernst (Basle) for the International Union of Biological Seiences, and Dr. L. G. F. Kalshoven (Blaricum) for the International Society of Soil Science. The resolutions which had been adopted at tho symposium on Termites in the Humid Tropics, arranged jointly by Unesco and the Zoological Survey of India at Delhi in October 1960, formed a basis for the discussions. It was agreed that the international co-operation desirable in termite resoarch, and in the dissemination of results of practical value in the control of termites as pests of buildings and crops, would best be achieved through Unesco. Among the projects suggested for early consideration and action were: (1) review of the influence of termite activity on soil fertility; (2) review of the methods used in combating termite damage to buildings and to tropical crops; (3) investigation of introduced termites, and of methods for restricting the spread of injurious spocies; (4) coordination of mothods for the laboratory testing of termite resistance in materials; (5) standardization of measurements used in termite taxonomy, and of terminologics used in termite biology.

\section{Refuse Disposal}

Every year local authorities in Great Britain dispose of nearly $100,000,000$ cubic yards of refuse, weighing about $13,000,000$ tons. $\mathrm{Up}$ to 20 per cent by weight of this is worth salvaging, and, as living standards rise, the proportion increases. Many local authorities havo central refuso sorting plants where these materials are extracted and sold back to industry. Stoke-on-Trent, for example, has an income from this source of $20 \mathrm{~s}$. for every ton of refuse handled. Local authorities are apt to be cautious in thoir approach to any positive change in their established practice of refuse disposal, but, if they had a statutory duty to protect the landscapo, carrying equal weight with their public health obligations, it is likely that the advantages offered by new methods of refuse and sewage disposal would compel their speedy adoption. The Sheffield and Peak District Branch of the Council for the Preservation of Rural England has published a usefuI pamphlet by J. C. Wylie on this subject which is specially valuable for the information it gives on composting in practice (price 2s.). The main advantages of composting are that no largo area of land is required; composting plants can be permanently placed in close proximity to the areas from which the refuse is collected; the composting process, when aerobically carried out, is hygienic and is not a nuisance. It offers a solution to the difficult problem of sewage sludgo disposal; no more manpower is called for than is required under present systems of disposal; the prospects for selling compost are excellent.

\section{Norsk Polarinstitutt, Arbok, for 1960}

THE Norsk Polarinstitutt has recently published tho first of a new series, its $A$ rbok (Yearbook) for 1960. This addition to the existing Skrifter (papers) and Meddelelser (communications) which have been pub- lished by the Institute for some years will fulfil several functions. It will contain the annual report of the Director, general information about the Norsk Polarinstitutt, information on scientific work carried out by forcign expoditions in Norwegian Arctic and Antaretic territories, and shorter scientific papers of general interest. In the 1960 Arbol, about 80 per cent of the text is in English, so its use will not be restricted to those with a knowledge of Norwegian. Shorter papers cover items such as the discovery of footprints of the dinosaur in the lower cretaceous of Vestspitzbergen, a discussion of the fossil Gigantaspis which has only been roported once before, and a general paper surveying height limits for vascular plants in Svalbard (in Norwegian). A short report of a glaciological survey of Maudheim in 1960, eight years after the station of the Norwegian-British-Swedish Antarctic Expedition was abandoned, throws useful light on processes of bottom melting and surface accumulation on ice sholves. A review in English on recently published Russian work on the bathymetry of the region between Spitsbergen and Greenland shows that the postulated Nansen Ridge connecting the two lands doos not exist, and a trough of more than $3,000 \mathrm{~m}$. in depth separates the two regions. Another useful survey is that on absolute age determinations on rocks from Dronning Maud Land, Antarctica, by recent Belgian, Japanese and Russian expeditions. Several other articles, the annual report and a short history of the Institute complete the Arbok.

\section{Scientific Research in British Universities and Colleges, $|96|-62$}

Scientific Research in British Universities has now been superseded by the Department of Scientific and Industrial Research's publication entitled Scientific Research in British Universities and Colleges (196162. Pp. xvii +622. London: H.M.S.O., 1962. 32s. $6 d$. net). The hand-book lists research being carried out at present in universities and colleges and advanced technical colleges and regional technical collegos in England and Wales and equivalent colleges in Scotland and Northern Ireland. It describes the nature of the project in sufficient detail to indicate the sort of research done by the various scientific departments and individual teams of investigators, but does not refer to the social science and industrial administration except where work in this field normally occurs within the science faculty or technical department. The format of the hand-book remains the same and the name- and subject-indoxes are separate. Copies of the hand-book are available from the Department of Scientific and Industrial Research, State House, High Holborn, London, W.C.1.

\section{Publications of the Instituto Antartico Argentino}

DURING recent years the Argentine Antarctic Institute has played an active part in developing scientific investigations of Antaretica. In addition to being responsible for the operation of the EllsworthGeneral Belgrano group of stations at tho head of the Weddoll Soa, the Institute has developed a good library, has a sciontific staff working on Antarctic results for publication, and is the main centre of Antarctic research in the Argentine. The symposium on "The Antarctic" hold there in 1959 was attended by 57 representatives of other countries, and was most suceessful as a means of exchanging early information on the results of research of the International Geophysical Year. The Institute publishes several sories which include the Boletin del Instituto Antartico 